\title{
A REMARK ON THE OLD NORSE CONJUNCTION OK
}

\author{
MARIT AAMODT NIELSEN
}

\section{Introduction}

The class of connectives or conjunctions is a relatively small, but important word class. Often very little attention is paid to this word class in handbooks and grammars in spite of its frequency. The main reason why this is so, is maybe because its members first and foremost contribute to the constitution of the textual level. Connectives primarily link and form relations between words, phrases and clauses, and often have very little semantic content in themselves whereas the main semantic content lies in the words and phrases.

Yet, for historical pragmatic syntax as well as for language history, the importance of this word class should not be totally overshadowed by the study of the elements that carry more semantic meaning. Connectives are intriguing because they often seem to develop in a rather translucent way and often quite fast in a language.

The two most common connectives in Old Norse are ok (and), en (but) (Barnes, 1999: 202f). I shall give a survey of the use of $o k$ in Old Norse (Part one), consider a susceptible candidate of a grammaticalization process leading to $o k$ as its result (Part two), and finally discuss whether the use of $o k$ in Old Norse is restricted to parataxis as in Modern Mainland Scandinavian today (Part three).

I will show that the function of $o k$, connective, and of $o k$, adverb, in Old Norse, is not so straightforward and clear-cut as it may seem at first glance. There might in fact be a more gradient transition between the two functions of $o k$ than normally accepted in most handbooks and grammars. 


\section{Part one: The use of $o k$ in Old Norse}

The main function of $o k$ in Old Norse is to be an additive coordinator, linking phrases and clauses. $O k$ corresponds to the word and in modern English. It survives in Modern Mainland Scandinavian (MMS) in a slightly modified form, as $o g$ in Modern Norwegian and Modern Danish, as och in Modern Swedish, and is also og in Modern Icelandic (written forms). The word $o k$ 's syntactic function is to link words, phrases and clauses, and parts of text.

Halliday and Hasan (1976: 233ff) stress that the modern English correspondent and partially functions as a logical coordinator (as in A+B), and partially as a cohesive element when it links larger linguistic units than words and phrases. Thus they distinguish between the use of and as an additive conjunction, and the use of and as a coordinator. The additive use is regarded to be a looser and less structural relation than the coordinative one.

I hold that the same distinction could be drawn for the Old Norse $o k$ as well as for its Modern Mainland Scandinavian variants. At one side of the scale $o k$ links words and phrases, and the linkage forms one syntactic constituent consisting of a proper coordination as you find under (1) and (2) below. On the other hand, it functions as an additive conjunction as in the clear example (4) where it links a main clause to its preceding context. Cases like (3), where $o k$ links two main clauses seem to imply a lesser degree of coordination and more of the additive function than case (2) where it links subordinate clauses. Compared to case (4) however, (3) conveys more of the coordinative and less of the additive function. Thus, the prototypical use of $o k$ exhibits some variation, which I tend to look at as a gradient parameter going from the clear case of structural coordination as in (1) to the clear case of textual cohesion as in (4). It should be noted, however, that the coordinative function of course also implies the additive function, but not the other way round:

(1) en peir Porkell ok Gísli váru heima bádir

“...but they, Porkell and Gísla, were at home both” (Gi 2,28)

(2) En ef hann brennr. ok verðr hann at pví kunnr ok sannr pá er hann utlægr...

"But if he burns (the house down) and is he found guilty, then is he outlawed..." (Gu 90,31)

(3) Aldri varð siðan jafnblítt með peim broeðrum, ok ekki pá Porkell vápnaskiptit... "Never became later as sweet with the brothers and not accepted Porkell the exchange of weapons..." (Gi 3,16)

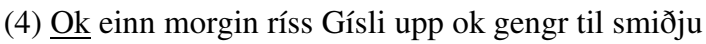

"And one morning gets Gisli up and goes to the forge"... (Gi 11,20)

As well as a coordinator and as an additive conjunction, $o k$ has very little semantic content in itself but for the conjunctive or additive, and it is always 
unstressed. Further it is bound to certain positions: As a coordinator its prototypical position is between the coordinated elements, and as an additive conjunction the prototypical position is in front of the element which is linked to another syntactic unit.

In Old Norse $o k$ forms a microsystem together with another conjunction, en, which besides the conjunctive meaning originally also conveys an adversative content, meaning, but. This neat system with $o k$ as an additive conjunction and $e n$ as an adversative one had already to some degree broken down in Old Norse in the sense that the adversative meaning of $e n$ seems to be bleached. In many cases en equals $o k$ when linking elements on the textual level, as in (5) and (6):

(5)... en peir Porkell ok Gísli...

“... but they, Porkell and Gisla... (Gí 2, 28)

(6) En ef hann brennr...

"But if he burns (the house down)... (Gu 90, 31)

In both these cases an adversative reading is possible, but not compulsory. It is therefore not very surprising that en disappears in the three MMS languages and is replaced by other words expressing adversity, probably due to the loss of clear adversative content. $O k$ however persists and survives, having an unequivocal content, and it comes to substitute en in positions where this conjunction conveyed no adversative meaning, that is, where the merely cohesive function of en was predominant (Christoffersen, 2003: 16ff.).

\section{Part two: Grammaticalization}

The conjunction $o k$ probably originates as a result of a grammaticalization process of an adverb, auk, in Protogermanic. The main reason for this belief is that the adverb still exists in Old Norse as $o k$ or $a u k$, and in Modern Mainland Scandinavian, as $o g$, och and $o g s a ̊ a u$ (dialectal) side by side with the grammaticalized conjunction (Braunmüller, 1995: 265f).

Foreign influence or borrowing, as well as internal reanalysis, are probably the main causes for conjunctions to develop and for change to take place. There is a strong universal tendency of grammaticalization, of conventionalizing ordinary phrases into conjunctions, in its turn leading to the reanalysis of the phrase as a conjunction and to further morphological and phonological development of the original form.

The term grammaticalization normally implies a loss of meaning, often called «semantic bleaching». I must, however, agree with Traugott and König (1991: 190f), who argue that although there is a loss of semantic content when a former ordinary 
phrase is reanalyzed as a conjunction, there incontestably also is a strenghtening of informativeness, of meaning of a more abstract kind. One might say that the alleged loss implies a loss of referentiality while there, on the other hand, is an increase in relational content or meaning. Specialized connectives and conjunctions strengthen the cohesion within sentences and clauses, between phrases and clauses as well as between larger textual units.

The adverb ok/auk differs from the coordinator $o k$ at least in three respects: First by carrying heavy stress in itself or functioning as a marker of stress on the following phrase, secondly by filling another canonic position in the sentence than the coordinator, and thirdly by having slightly more semantic content than the coordinator, meaning 'also, as well, further', thus conveying a disambiguating or deictic and to a certain degree sequential meaning as well. It shares with the conjunction the function as a cohesive element in the clause.

The canonic position of $o k / a u k$ with adverbial function is sentence internal, after the finite verb form, as in (7), where it functions as a modifier of the sentence:

(7)...get ek ok, at auðni ráđa nú um petta

“...think I also that fate will decide about this" (Gí 9,19)

Or its position is just in front of an element focussed by ok, like in (8):

(8) Peir skiptu ok úmegð

"They shifted also the legally incompetent" (Gí 15,11)

To sum up so far:

All the Old Norse cases cited above, are clear-cut examples of either conjunction or adverb, when it comes to position, stress and semantic meaning.

But as shown below, Old Norse also exhibits less prototypic cases where the borderline and thus the distinction between the two functions, conjunction or adverb, seem to be more obscure or blurred, and cases where $o k$ seems to replace other subordinators.

\section{Part three: Parataxis or hypotaxis?}

First I comment on the function of $o k$ in sentence-initial position where $o k$ normally is a marker of parataxis, and secondly on the function of $o k$ where $o k$ seems to replace some other adverb or conjunction with more specialized functions normally signalizing hypotaxis.

It should be noted that Old Norse is a verb second language with SVO (subjectverb-object) as the unmarked word order pattern (Christoffersen, 1979: 119; Christoffersen, 1993: 305ff; Faarlund, 1990: 52). Further, Old Norse has a TVS-pattern, $\mathrm{T}$ stands for topic, when a constituent other than the subject is topicalized, like in 
(4) which I now invite you to cast a brief glance at again, where the adverbial phrase, einn morgin, is topicalized. But Old Norse also exhibits a VSO-pattern, used when no element is topicalized, as you see in (9) below, where the finite verb form, gengr introduces the sentence. This VSO-order is interpreted as an implicit context marker by most scholars.

(9) Gengr húsfreyja til dura

"Goes the housewife to the door" (Gí 40, 22)

When introducing a TVS-structure, like in (4) above, there can be no doubt that $o k$ functions as a conjunction, due to the verb second constraint. When $o k$ precedes the VSO-order, however, as in (10), the question arises whether this $o k$ is a conjunction preserving the VSO-order, or whether it is an adverb, yielding a TVS- structure.

$\mathrm{OK}$ may clearly be conceived as a conjunction also in this position (Christoffersen, 1993: $53 \mathrm{ff})$ :

(10) Ok ríða peir sína leið

"And ride they their way" (Gí 40,22)

One might say that the textual coherence, usually expressed by the VSO-order alone, in (10) so to speak is made explicit by the very presence of the coordinator. The occurrence of $o k$ in these cases thus intensifies the coherence, but the coordinator in itself is redundant or superfluous and normally carries no stress.

However, to the left of an initial finite verb form, like in (10) there incontestably is room for a proper constituent with semantic content as well. And nothing prevents us from stressing a constituent in this position. Thus, the initial ok displayed in (10) and thousands of similar examples could theoretically be the adverb ok/auk and not the conjunction $o k$.

Nygaard (1905: 347) as well as Faarlund (1985: 375) advocate that $o k$ in initial position preceding a VSO-order as in (10) in fact is more 'adverb-like' than 'conjunction-like'. Faarlund (1985: 375) states the following about the word $o k$ in this position: "Despite its meaning, it still retained (at least for a period) its adverbial status, triggering inversion".

Thus, Nygaard and Faarlund seek the reason for the inversion after $o k$ in the status of the word $o k$ itself, and not in the textual coherence.

However, numerous examples of VSO-order without any ok present, here represented by (9), indicates that an interpretation of $o k$ in initial position as an explicit, but totally unstressed coordinator, rather empty of communicative content, and not as a stressed adverbial $o k / a u k$, probably is more justified. It is not the presence of $o k$ in itself that triggers inversion, but the inversion per se that is a context marker.

Also cases with initial unstressed $o k$, preceding a TVS- structure, lead to the interpretation of initial $o k$ being a conjunction and not the adverbial modifier, ok/auk 
(Christoffersen, 1993: 53f). Initial position seems to be one of the canonical positions of $o k$ as an additive coordinator, as in (4), and not of $o k$ as an adverb.

Secondly, I will focus on the intriguing phenomenon that the word $o k$ seems to be able to replace other adverbs and conjunctions with more specific relational meanings in Old Norse, like the temporal and causal adverb pá, meaning 'then' or 'in this case', which normally introduces a main clause, or the relative particle er, meaning 'that', introducing a subordinate, often relative, clause (Christoffersen, 2003: 17f).

The replacement of $p a$ by $o k$ is very common in Old Icelandic, while the replacement of $e r$ by $o k$ generally occurs in Old Norse, albeit not very frequently.

These cases illustrate a point underlined by Braunmüller (1985: 265): The use of conjunctions at earlier stages of the languages may be less precise or specific than at later stages, and further that the line between parataxis and hypotaxis may be somewhat blurred.

Example (11) below illustrates the normal use of $p a ́$ in its causal function: $p a ́$ so to speak resumes the content of the preceding left-dislocated conditional clause. Thus this adverb relates the content of the conditional clause to the rest of the sentence (Christoffersen, 1993: 187).

(11) En ef sá eiðr fellr, bá er hann sannr at udáðan

"But if this oath falls, then he is guilty of the crime" $(\mathrm{Gu}, 49,5)$

In (12), however, $p a ́$ seems to be replaced by $o k$ :

(12) Ef sótt er á barni, ok skal par skíra er vatni náir fyrst

"If illness is on the child, and shall (it) there baptize where water is reached first" (Grágás, 4,22)

$O k$ in (12) apparently substitutes a more specialized adverb, which function is to establish a causal or temporal cohesion between parts of the sentence as a whole. The syntactic connection when ok comes to replace $p a ́$, seems much looser than when $p a ́$ is used, leading Nygaard (1905: 270 ff) in his authoritative Norrøn Syntax to consider such substitutions as mistakes or as what he calls "confused and mixed analogies".

The common trait shared by the words $o k$ and $p a$ is a general semantic cohesive function, which maybe legitimates the substitution that takes place here.

One should also bear in mind the fact that coordination in the linguistic sense does not always equal a straightforward addition in its strict mathematical sense. The relative ordering of the linguistic elements $\underline{x}$ and $y$ may depend on the ordering of events par example in time or sequence. Even in simple coordinations there might be a sort of natural ordering, par example in expressions like morning and evening, fathers and sons. Also between main clauses in modern everyday language, even 
when the second clause is introduced by some equivalent to $o k$, there is often some sequential order making the reverse order of the elements unacceptable.

Thus, because addition also may convey an implicit order in time or sequence, $o k$ might be chosen instead of $p a ́$. The slight sequential content sometimes expressed by $o k$ maybe permits it to be used also as a more general expression of sequence.

Till now I have treated the conjunction $o k$ that comes to replace $p a ́$ as if it were the coordinator $o k$. This reading is not without problems however, because the cohesive element here seems to link two parts of a clause, of which the first part is a subordinate, having as a result a rather ill formed sentence, it must be admitted. On the other hand, $o k$ occupies the normal conjunctional position, but a normal reading of example (12) would imply heavy stress on $o k$. So could it be that this $o k$ is the adverb $o k$ ? I hold that a reading of $o k$ as a stressed adverb instead of a coordinator in such cases is by no means farfetched, because $o k$ literally replaces another adverb. It must be read with heavy stress, and the semantic content may be interpreted as more explicitly sequential than normally is conveyed by the coordinator. This reading does not render the sentence more acceptable from a strictly grammatical point of view, though.

Whereas the syntactic status of $o k$ instead of $p a$ slightly biases in favor of the adverb $o k$, as we have seen, a different conclusion must probably be drawn concerning the substitution of the relative particle er/sem, by $o k$. An unstressed $o k$ here seems to introduce a dependent clause, as you see in (13), compared to the normal relative formation in (14). I hold this $o k$ clearly to be more conjunction-like than adverb-like:

(13) Sigurðr gengr at móti með sitt sverð, ok Gramr heitir...

"Sigurd goes towards (him) with his sword and Gramr is called"... (Nygaard, 1905:270)

(14) Kólr, præll minn, á sverð, er Grásíða heitir...

"Kol, my slave, owns a sword that Grasida is called..." (Gí, 2,2)

The particle $e r$ in itself has a multitude of functions in Old Norse. As Barnes (1999: 204) puts it: "Old Norse $e r$ is an all-purpose subordinating conjunction. Having lost any meaning of its own, it is used to introduce a wide variety of dependent clauses, either alone or together with one or more other words".

But how can the coordinator ok replace $e r$ as a relative? I think this is due to a kind of analogy. In many cases, it seems that $e r$ as a relative is substituted by $e n$. As we saw above, $o k$ might substitute $e n$. Therefore the way might not be long for $o k$ to replace $e r$ in this position as well (Christoffersen, 2003:17f). The conjunction $o k$ seems to dominate and even is fit to substitute other connectives with a more specific semantic content, like the causal adverbial $p a ́$, or the relative particle $e r$. 


\section{Conclusion}

Whereas modern languages like English or Modern Mainland Scandinavian seem to draw a rather strict borderline between cases of parataxis and cases of hypotaxis, this is not always the case at the older stages of the languages. Neither is the use of the different connectives always as differentiated or specialized as at later stages. Yet I hold that substitutions, albeit strange and unexpected from a modern point of view, may be semantically and functionally motivated.

Note: An earlier version of this paper was originally read in 2001 at The 15th International Conference on Historical Linguistics, Melbourne, Australia, 13-17. August 2001.

\section{Literature}

Barnes, M. 1999. A new introduction to Old Norse. London: University College London.

Braunmüller, K. 1995. "Remarks on the formation of conjunctions in Germanic languages". In: Braunmüller, K. (ed.). Beiträge zur Skandinavistischen linguistik. Oslo: Novus. 247-272.

Christoffersen, M. 1979. "Marked and unmarked word order in Old Norse". CILT 14. 115-121.

Christoffersen, M. 1993. Setning og sammenheng. Syntaktiske studier i Magnus Laga bøters landslov. ADH-serien 65. Kristiansand: Agder distriktshøgskole.

Christoffersen, M. 2003. "Noe om bindeord i eldre norsk, særlig om ok, en og nema". In: Faarlund, J.T. (ed.). Språk i endring. Indre norsk språkhistorie. Oslo: Novus Forlag. 13-28.

Faarlund, J.T. 1985. "Pragmatics in diachronic syntax". Studies in Language 9. 363-393.

Loth, A. (ed.). (1968). Gí=Gísla saga Súrssonar [The saga of Gisli]. Nordisk filologi 11. København: Munksgaard.

Eithun, B., Rindal, M. and T. Ulset. 1994. Gu=Den eldre Gulatingslova [The Law of Gulathing]. Norrøne tekster 6. Oslo: Riksarkivet.

Finsen, V. 1852-1883 (repr. 1974). Grágás [The Icelandic law called The grey goose] I-III. Odense: Odense Univeristy Press.

Halliday, M. and H. Ruqaiya. 1976. Cohesion in English. Longman: London.

Hopper, P. and E. Traugott. 1993. Grammaticalization. Cambridge: Cambridge University Press.

Nygaard, M. 1905. Norrøn syntax. Kristiania: H. Aschehoug and Co.

Traugott, E.C. and E. König. 1991. The semantics-pragmatics of grammaticalization revisited. Grammaticalization I. Amsterdam/Philadelphia: John Benjamins. 189-218. 